\title{
Comparison of the Specialist Medical Training in Internal Medicine between Germany, Austria and Switzerland: An Overview
}

\author{
Johanna Braun*, Ursula Gresser \\ Internal Medicine, Medical Faculty, Ludwig Maximilians University of Munich, Munich, Germany \\ Email: ^hannah.b@gmx.de
}

How to cite this paper: Braun, J., \& Gresser, U. (2017). Comparison of the Specialist Medical Training in Internal Medicine between Germany, Austria and Switzerland: An Overview. Creative Education, 8, 1729-1741.

https://doi.org/10.4236/ce.2017.811118

Received: May 2, 2017

Accepted: September 1, 2017

Published: September 4, 2017

Copyright $\odot 2017$ by authors and Scientific Research Publishing Inc. This work is licensed under the Creative Commons Attribution International License (CC BY 4.0).

http://creativecommons.org/licenses/by/4.0/

\begin{abstract}
Specialists for internal medicine are very important group of the medical profession. Although they make up the largest group of specialized physicians, there is a shortage of physicians, and in particular of internists in Germany, Austria and under some aspects in Switzerland. Germany, Austria and Switzerland show also an intensive transfer of physicians. It is therefore of interest to investigate if the tern "internist" in the three countries under consideration is based on the same or equivalent education, in particular regarding the quality standards. Exchange date between the three countries, the organisation of the medical profession, the access requirements to the specialist medical training, the structure of the specialist's training as well as the requirements for keeping the specialist's name have been compared. The main differences are the access requirements and the linkage of the qualification to the independent exercise of the medical profession. Also regarding the performance catalogues, the Swiss education follows a different approach as in Germany and Austria.
\end{abstract}

\section{Keywords}

Specialist, Internal Medicine, Specialist's Training, Germany, Austria, Switzerland

\section{Introduction}

Specialists in internal medicine are deeply rooted in the healthcare system.

The importance of specialists in internal medicine is exhibited by the sheer size of this specialist group compared to any other group in the entire medical profession. In 2015, the specialists for internal medicine in Germany comprised 
of 50,834 people while the total number of physicians was 371,302 people (BÄK, 2016a, Statista, 2016a). In Switzerland, the statistical evaluation for 2015 shows a total of 35,325 physicians, with 8328 specialists for General Internal Medicine (Hostettler \& Kraft, 2016), followed by the specialists for psychiatry and psychotherapy. The same applies to Austria, in 2015, the internists made up the largest specialist medical group with 4204 members. The total number of physicians the same year was 44,002 (Statistik Austria, 2016a). Thus, the physicians specialized in internal medicine represent the largest group with a specialisation in Germany, Switzerland and Austria.

The main reason why internists make up the largest specialist medical group is due to the increase in life expectancy. The share of older citizens with care needs in the field of internal medicine has grown substantially as a result of the generally increasing life expectancy (Sieber, 2007, Statistisches Bundesamt, 2015). Furthermore, early diagnosis and long-term therapy of chronic diseases, as well as current surgical therapy options often require life-long aftercare (such as type I diabetes mellitus) (Orchard et al., 2015).

A parallel phenomenon is the deficit of physicians due to the migration movements within the specialist groups (B̈̈K, 2015, Schmidt \& Gresser, 2014). Migration movements to Germany, especially from Austria, have been documented (in 2015, 2573 doctors moved to Germany from Austria (BÄK, 2016a)) and Eastern European countries, with a negative migration balance for Germany (Schmidt, 2014; Wismar et al., 2011). At the same time, there is a movement of physicians from Germany to Switzerland (in 2015: 629 Germany doctors moved to Switzerland, in contrast to 252 physicians from Switzerland to Germany). Austria is in second place (in 2015: 264 doctors moved to Switzerland) (BFS, 2015, BAG, 2016a). In Switzerland, German physicians are the highly represented group of foreign physicians (Statista, 2016b).

The preceding data thus show the intensive transfer of doctors between the three countries.

This raises the question whether the commonly used term "internist" or "specialist physician for internal medicine" in the three countries under consideration is based on the same or equivalent education, in particular regarding the quality standards. Can patients and employers rely on the fact that the physician trained abroad can meet the qualifications required in the target country?

The results section starts with a comparison of the exchange of physicians between the three reviewed countries. Then, the organisation of the medical profession in the three countries and the access requirements for the specialist medical training are shortly summarized. More focus has been put on the structure and content of the specialist's training as well as on the requirements for keeping the specialist's name. The main and most relevant commonalities and differences in the specialist's training in internal medicine are then emphasized in the discussion section. The conclusions section gives then a short summary of the most important insights and a prospect of the situation. 


\section{Results}

\subsection{Physician's Exchange between Germany, Austria and Switzerland}

In Germany, the number of working physicians has risen by $21.1 \%$ from 306,400 (BÄK, 2005) to 371,302 (BÄK, 2016a) between 2005 and 2015. Nevertheless, one speaks generally of a medical deficit (Adler and Knesebeck, 2011, Stackelberg, 2010).

For German physicians, Switzerland is followed by Austria as the most popular migrant countries (B̈̈K, 2016a; Kopetsch, 2010, Statistisches Bundesamt, 2011). In 2014 and 2015, respectively, 285 and 264 German physicians (BÄK, 2016a) migrated to Austria. In 2014 and 2015, 629 German physicians migrated to Switzerland (B̈̈K, 2016a).

In Germany, emigration is caused by unsatisfactory working conditions both in the inpatient as well as in the outpatient sector (van den Bussche et al., 2012).

In Austria, the main reasons for emigration are long working hours, low wages compared to neighbouring countries and deficits in medical education (Scharer and Freitag, 2015; Wismar et al., 2011).

The highest exchange is with the neighbouring countries. Germany and Switzerland are the most popular migrant countries of the Austrian medical community (Wismar et al., 2011; Zimmermann and Purger, 2015). This is justified by the common language (Wismar et al., 2011).

Switzerland is a country of immigration for physicians (Jaccard Ruedin \& Widmer, 2010). The number of doctors in Switzerland is assured by feminization and immigration (Kraft and Hersperger, 2011). Nevertheless, there is a shortage of doctors in Switzerland, since the number of doctors trained in Switzerland does not cover the needs (Kraft and Hersperger, 2011).

In 2014, 17\% of physicians working in Switzerland had a German degree (Hammer, 2015; Statista, 2016b). In 2015 it was already 17.7\% (Hostettler \& Kraft, 2016).

The same language (at least for the German-speaking part of Switzerland), higher salaries and better health system conditions compared to Germany are cited as reasons for their relocation (Bundesrat, 2011).

The migration movement in the countries of Germany, Austria and Switzerland therefore differs significantly. For Germany, emigration is predominant over immigration (BÄK, 2016a; B̈̈K, 2015; B ̈̈K, 2014a; B ̈̈K, 2013a; BÄK, 2012; B ̈̈K, 2011a; Wismar et al., 2011). In Austria, emigration and immigration are largely balanced (Wismar et al., 2011). Switzerland shows a positive immigration balance (BAG, 2016a; Hostettler \& Kraft, 2016).

\subsection{Organisation of the Medical Profession}

In Germany, the medical profession is organized in the Federal chamber of physicians as well as the corresponding 17 provincial chambers (B ̈K, 2014b). The provincial chambers are subdivided hierarchically into district and circuit asso- 
ciations. The membership in the regional chamber of physicians and the district chamber is obligatory for every physician active in Germany and is regulated in the Heilberufe-Kammergesetz ( $\mathrm{HKaG}, 2002)$ of the respective federal state. This obligatory membership leads to the indirect membership of every physician working in Germany to the Federal chamber of physicians (BÄK, 2016b) by means of the affiliation of the regional chambers. The chamber of physicians is also responsible for the continuing medical education (HKaG, 2002).

The medical profession in Austria is organized in the Austrian medical association (ÖÄK, 2016a). As an umbrella association, all nine provincial chambers are members of the Austrian chamber of physicians (Ö̈̈K, 2016a). Doctors are, by law, members of the medical chamber responsible for them (ÄrzteG, 1998). The Austrian Chamber of Physicians is also responsible for further training as a specialist (ÄrzteG, 1998; ÖÄK, 2015a).

The central body of the medical profession in Switzerland is the Swiss medical association "Foederatio Medicorum Helveticorum", FMH (FMH, 2016a). All cantonal and specialist medical societies (FMH, 1998) are organized in the FMH. In order to become a member of the $\mathrm{FMH}$, a federal or equivalent medical diploma (FMH, 1998) is required. The membership is not mandatory per se, but is required to carry an FMH specialist medicine title earned in Switzerland (FMH 1998). The legal provisions for the acquisition of a specialist doctor's title are laid down in the training regulations (SIWF FMH ISFM, 2002a), for which the FMH is responsible (FMH, 1998).

Table 1 summarizes the essential information on the organization of the profession in Germany, Austria and Switzerland.

\subsection{Access Requirements for the Specialist Medical Training}

In Germany, training to become a specialist can only be started after the suc-

Table 1. Comparison of the organisation of the medical profession.

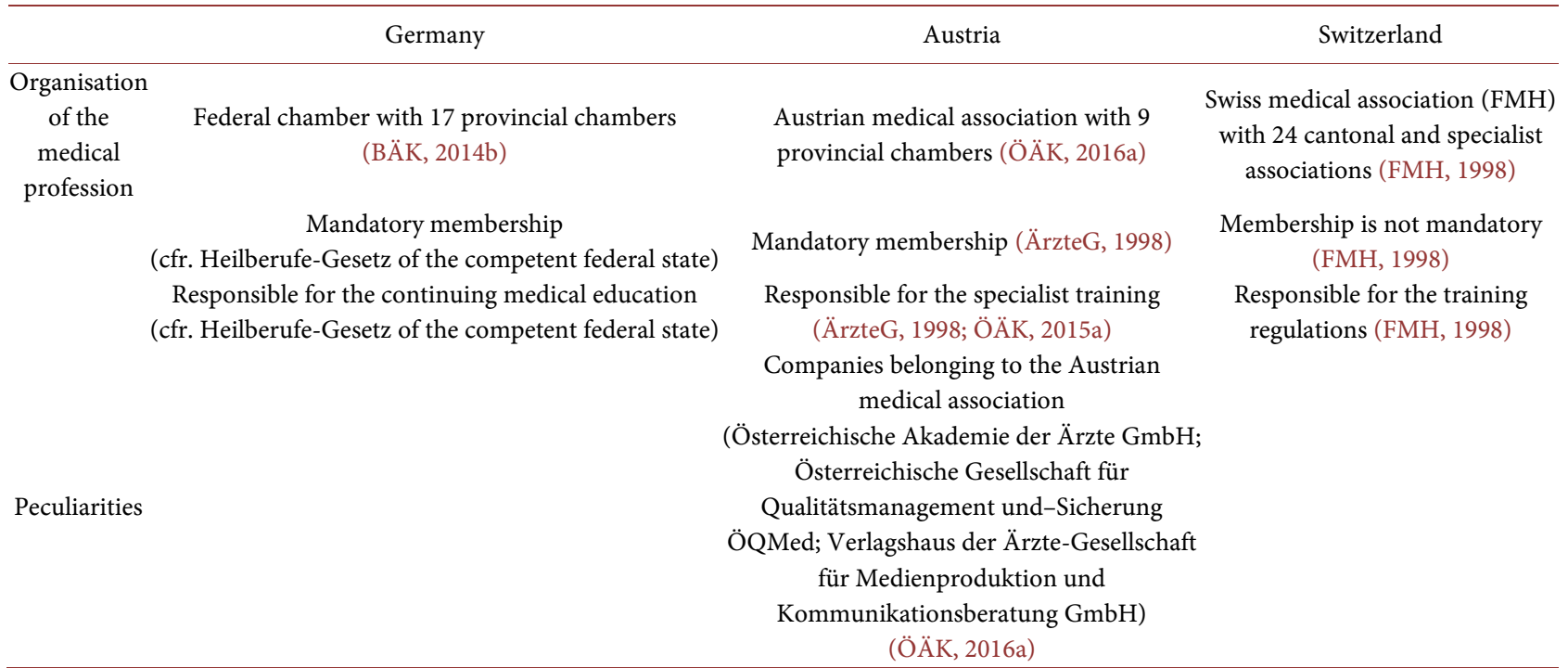


cessful completion of the medical studies, which encompasses the third medical state examination and the licence to practise medicine (BÄK, 2003). An exception here is the specialist training for oral-maxillofacial surgery. In this case, the prerequisites are the third medical state examination and the dental examinations (B̈̈K, 2003).

In Austria, the prerequisite for the start of the specialist training course is the successful completion of the study of human medicine, consisting of the oral examination and the submission of a diploma thesis (ÄrzteG, 1998; ÖÄK, 2015b). The physician is however not entitled to exercise the medical profession independently (ÄrzteG, 1998). He now owns the so-called Ius operandi (ÄrzteG, 1998; Fisch, 2008). After completion of the general medical training or specialist training, the Austrian physician receives the right to self-employment (Ius practicandi) (Fisch, 2008) and may call himself a physician for general medicine or specialist physician (ÄrzteG, 1998). The term physician for general medicine (“Arzt für Allgemeinmedizin”) does not correspond to a specialist title (ÖÄK, 2015b).

In Switzerland, the prerequisite for the start of the specialist training course is the successful completion of medical studies with the acquisition of the Swiss doctor's diploma (SIWF FMH ISFM, 2000). Like in Austria, the physician is not entitled to exercise the medical profession independently (MedBG, 2006).

Table 2 summarizes the access requirements in Germany, Austria and Switzerland.

\subsection{Structure and Content of the Specialist's Training}

In Germany, the training period for the specialist for internal medicine is 60 months, 36 of which have to be completed as inpatient basic training in the field of internal medicine and 24 months as inpatient further training in internal medicine (BÄK, 2003). The content of the training is regulated in the training regulations (BÄK, 2003). The guidelines on the content of the specialist training contain indications over the number of required treatments and examinations to be carried out during the specialist training (B̈̈K, 2003b).

Table 3 shows an overview of the different specialist medical trainings in Germany.

Table 2. Access requirements for the specialist medical training.

\begin{tabular}{|c|c|c|c|}
\hline & Germany & Austria & Switzerland \\
\hline Prerequisites & $\begin{array}{l}\text { Passing the third medical state } \\
\text { examination and possession of the licence to } \\
\text { practise medicine (BÄK, 2003) }\end{array}$ & $\begin{array}{l}\text { Completion of the study of human medicine; } \\
\text { Handling over of a training plan } \\
\text { (ÄrzteG, 1998; ÖÄK, 2015b) }\end{array}$ & $\begin{array}{l}\text { Completion of medical studies } \\
\text { (Swiss doctor's diploma) } \\
\text { (SIWF FMH ISFM, 2000) }\end{array}$ \\
\hline Peculiarities & $\begin{array}{l}\text { Entitlement to exercise the medical profession } \\
\text { independently (BÄO, 1961) }\end{array}$ & $\begin{array}{l}\text { No entitlement to exercise the medical } \\
\text { profession independently } \\
\text { (ÄAO, 2015; ÄrzteG, 1998; ÖÄK, 2015b) }\end{array}$ & $\begin{array}{l}\text { No entitlement to exercise the } \\
\text { medical profession independently } \\
\text { (MedBG, 2006); Final specialist } \\
\text { exam in german, french, italian or } \\
\text { english language } \\
\text { (SIWF FMH ISFM, 2000) }\end{array}$ \\
\hline
\end{tabular}


Table 3. Overview of the specialist medical trainings in Germany.

\begin{tabular}{|c|c|c|c|c|}
\hline Germany & General Medicine & Internal Medicine & Surgery & Other Specializations \\
\hline \multicolumn{5}{|l|}{72 months } \\
\hline 60 months & $\begin{array}{l}\text { further training in the } \\
\text { outpatient general } \\
\text { practitioner's care } \\
\text { (24 months) }\end{array}$ & $\begin{array}{l}\text { inpatient further } \\
\text { training } \\
(24 \text { months })\end{array}$ & $\begin{array}{l}\text { further training in } \\
\text { the specialist field } \\
\text { (48 months })\end{array}$ & heterogeneous \\
\hline $\begin{array}{l}36 \text { months } \\
24 \text { months }\end{array}$ & $\begin{array}{c}\text { inpatient basic } \\
\text { training ( } 36 \text { months) }\end{array}$ & $\begin{array}{l}\text { inpatient basic } \\
\text { training } \\
\text { (36 months) }\end{array}$ & $\begin{array}{l}\text { Basic training } \\
\text { (24 months) }\end{array}$ & $\begin{array}{c}\text { structure } \\
\text { (48 to } 72 \text { months) }\end{array}$ \\
\hline
\end{tabular}

The training of specialists in Austria lasts 72 months and includes a nine months basic instruction for all physicians, where knowledge in conservative as well as in surgical fields is imparted ( $\mathrm{AAO}, 2015)$. The basic training is then followed by a 27 -month basic training course and a 36-month specialized training in internal medicine ( $\ddot{A A O}, 2015)$. Also in Austria, a minimum number of different treatments and examinations have to be carried out during the specialist training course for internal medicine (ÄrzteG, 1998; ÖÄK, 2015c).

Table 4 shows an overview of the different specialist medical trainings in Austria.

The duration of training as a specialist for internal medicine in Switzerland takes a total of 5 years (SIWF FMH ISFM, 2000). Three years must be completed in general internal Medicine. This is referred to as common basis training (SIWF FMH ISFM, 2000, SIWF FMH ISFM, 2011). The remaining two years can be completed in the two freely selectable modules of hospital internist and family doctor (SIWF FMH ISFM, 2011). They are referred to as further training (SIWF FMH ISFM, 2000). At least one year of training is to be completed in another hospital as a second training centre (SIWF FMH ISFM, 2011).

Table 5 shows an overview of the different specialist medical trainings in Switzerland.

Table 6 shows a comparison of the evaluation procedure and duration for the training as a specialist in internal medicine in Germany, Austria and Switzerland.

\subsection{Requirements for Keeping the Specialist's Name}

In Germany, the occupational regulations oblige physicians active in Germany to carry out continuous training (B̈̈K, 2011b). Within five years, $250 \mathrm{CME}$ points (Continuing Medical Education Points) must be collected (BÄK, 2013b). In Austria, continuing education is also mandatory. Similarly to Germany, 250 continuing education points are required within five years (ÖÄK, 2006; ÖÄK, 2010).

In Switzerland, the mandatory continuous training requests 50 training credits and 30 hours of self-study, which must be documented, on a yearly basis (SIWF FMH ISFM, 2002a).

Table 7 shows a comparison of the requirements for keeping the specialist's name in Germany, Austria and Switzerland. 
Table 4. Overview of the specialist medical trainings in Austria.

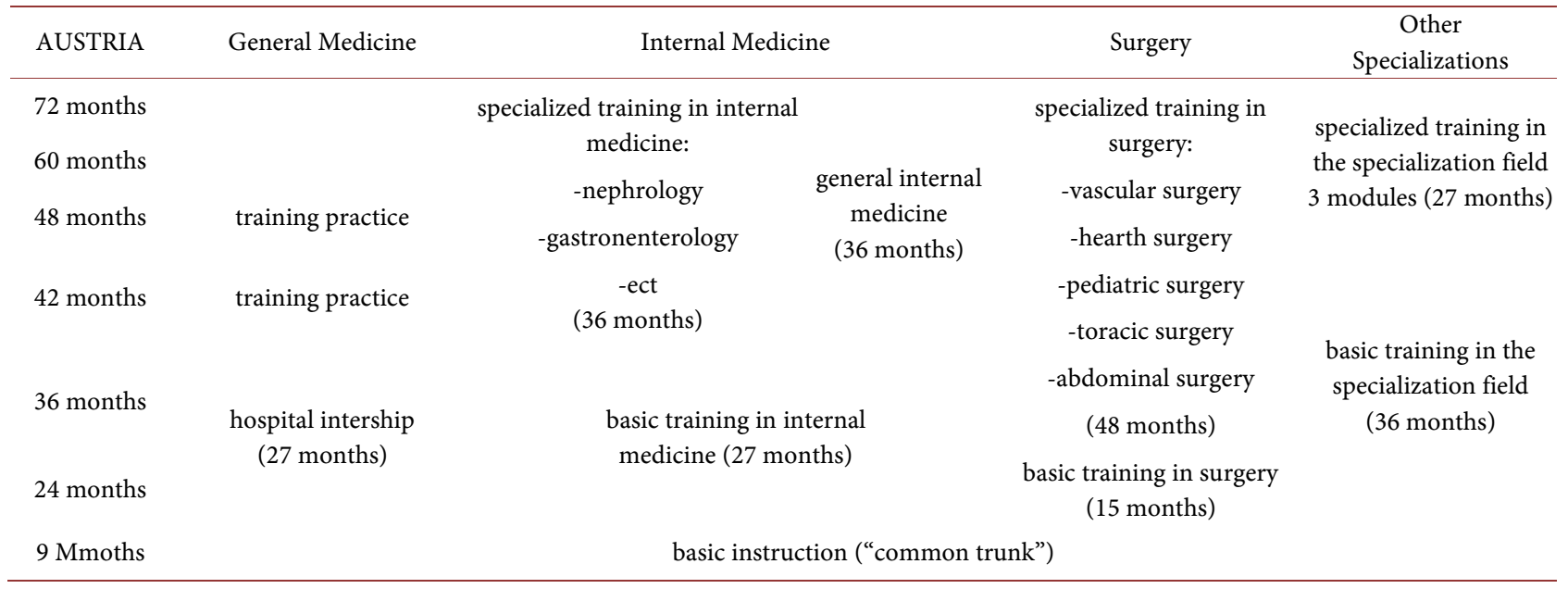

Table 5. Overview of the specialist medical trainings in Switzerland.

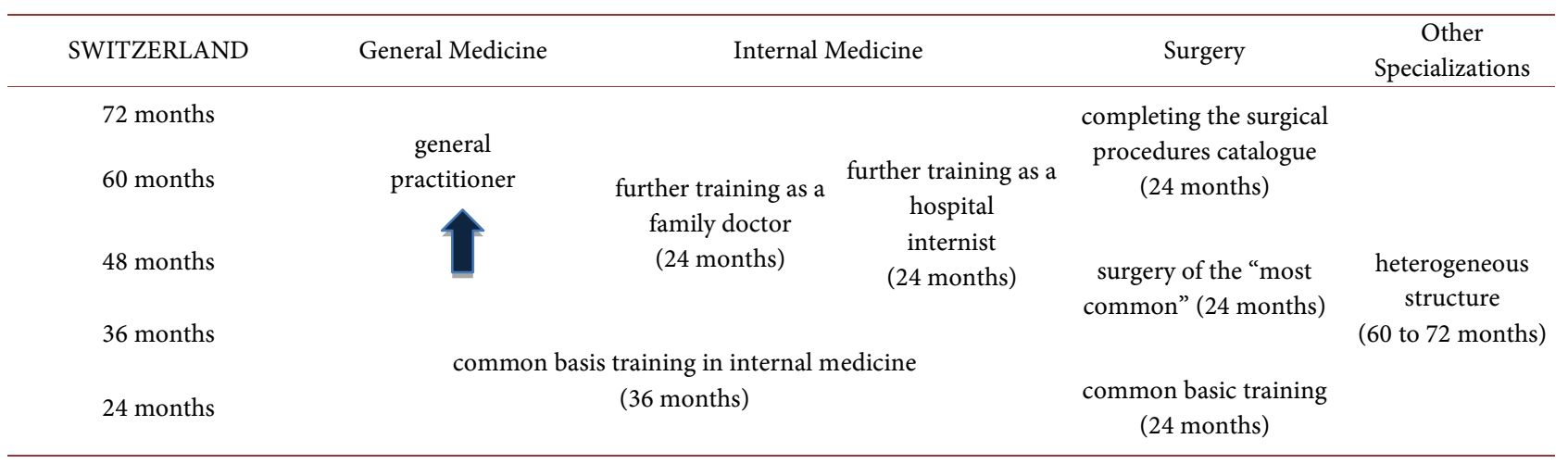

Table 6. Evaluation procedure and duration of the specialist medical training.

\begin{tabular}{|c|c|c|c|}
\hline & Germany & Austria & Switzerland \\
\hline $\begin{array}{l}\text { (Intermediate) } \\
\text { evaluation during } \\
\text { the training }\end{array}$ & $\begin{array}{l}\text { After completion of the respective } \\
\text { training section, however at least } \\
\text { once yearly }(\mathrm{BÄK}, 2003)\end{array}$ & $\begin{array}{l}\text { After completion of the respective } \\
\text { training section (ÄAO, 2015) }\end{array}$ & Yearly (SIWF FMH ISFM, 2000) \\
\hline $\begin{array}{l}\text { Duration of the } \\
\text { training }\end{array}$ & $\begin{array}{l}60 \text { months; } 36 \text { thereof as inpatient } \\
\text { basic training and } 24 \text { thereof as } \\
\text { inpatient further training in internal } \\
\text { medicine (BÄK, 2003) }\end{array}$ & $\begin{array}{l}72 \text { months; } 9 \text { thereof as a basic } \\
\text { instruction; } 27 \text { thereof as a basic } \\
\text { training in internal medicine and } \\
36 \text { thereof as specialized training in } \\
\text { internal medicine (ÄAO, 2015) }\end{array}$ & $\begin{array}{l}60 \text { months; } 36 \text { thereof in as common basis training in } \\
\text { internal medicine and } 24 \text { thereof as a further training } \\
\text { (family doctor or hospital internist) } \\
\text { (SIWF FMH ISFM, 2000) }\end{array}$ \\
\hline Peculiarities & & & $\begin{array}{l}\text { At least } 1 \text { year in a different hospital } \\
\text { (SIWF FMH ISFM, 2011) }\end{array}$ \\
\hline $\begin{array}{l}\text { Emergency } \\
\text { medicine }\end{array}$ & 6 months (BÄK, 2003) & & $\begin{array}{l}\text { At least } 3 \text { months in a recognized emergency unit of } \\
\text { the cat. IV (SIWF FMH ISFM, 2011) }\end{array}$ \\
\hline
\end{tabular}

\section{Discussion}

\section{Commonalities and Differences in Training as a Specialist for Internal Medicine in Germany, Austria and Switzerland}

The differences are the access requirements and the linkage of the qualification 
Table 7. Requirements for keeping the specialist's name.

\begin{tabular}{cccc}
\hline & $\begin{array}{c}\text { Germany } \\
(\mathrm{BÄK}, 2013 \mathrm{~b})\end{array}$ & $\begin{array}{c}\text { Austria } \\
(\text { Ö̈K, 2010) }\end{array}$ & $\begin{array}{c}\text { Switzerland } \\
\text { (SIWF FMH ISFM, 2002a) }\end{array}$ \\
\hline $\begin{array}{l}\text { Mandatory } \\
\text { continuing } \\
\text { education }\end{array}$ & $\begin{array}{c}\text { 250 CME points within 5 } \\
\text { years; Distance learning over } \\
\text { medical magazines is possible }\end{array}$ & $\begin{array}{c}\text { 250 continuing } \\
\text { education points } \\
\text { within 5 years }\end{array}$ & $\begin{array}{c}\text { 50 training credits and 30 } \\
\text { hours self-study per year }\end{array}$ \\
\hline
\end{tabular}

to the independent exercise of the medical profession to the specialist title. After the successful completion of the 3rd state examination and the acquirement of the licence to practise medicine, German doctors acquire the qualification for independent medical profession (B̈̈O, 1961). In Switzerland, the training title "general practicioner" (praktischer Arzt) or a specialist title are necessary for independently practising the medical profession (MedBG, 2006; SIWF FMH ISFM, 2002b). In Austria, after completing their studies in human medicine, the doctors do not have the qualification for self-employed medical activities (ÄrzteG, 1998). Self-employed medical practice requires the completion of at least 42 months of general medical training or the acquisition of a specialist medical examination (ÄAO, 2015; ÄrzteG, 1998).

If the performance catalogues are compared, the Austrian and the German performance catalogue show clear similarities. This is different with the Swiss performance catalogue, which defines basic illnesses and problems in which basic skills are developed and in which certain levels of competence must be acquired in the form of skills, abilities and knowledge (SIWF FMH ISFM, 2016a; SIWF FMH ISFM, 2016b). In the course of focus specialist training (hospital internist or family doctor), competencies must be acquired in connection with multimorbid disease pictures (SIWF FMH ISFM, 2016c; SIWF FMH ISFM, 2016d). Such a classification of the competences to be acquired according to specific diseases is thus not found in the Austrian or the German performance catalogue.

The recognition of the specialist designation between Austria, Germany and Switzerland is regulated by law in the EU Directive 2005/36/EC (EUR-Lex, 2005) and the bilateral agreement with Switzerland (Freizügigkeitsabkommen, 1999). The specialist titles listed are recognized and the correspondences of the specialist medical records in the country of origin to the correspondences of the specialist physicians in the target country are also laid down. In Germany and Austria the title "specialist for internal medicine "(Facharzt für Innere Medizin) exists. The equivalent training in Switzerland leads to the title "specialist for general internal medicine" (Facharzt für Allgemeine Innere Medizin) (BÄK, 2003; ÖÄK, 2015a, SIWF FMH ISFM, 2000). In particular, it should be noted that the term "specialist physician for general medicine" (Facharzt für Allgemeinmedizin) exists in the German education curriculum but is not identical to the Swiss "specialist for general internal medicine" (Facharzt für Allgemeine Innere Medizin) (BÄK, 2003; SIWF FMH ISFM, 2000). The same applies to the Swiss title "general practitioner" (Praktischer Arzt) and the Austrian "general practitio- 
ner” (Arzt für Allgemeinmedizin) (ÄAO, 2015; MedBG, 2006; SIWF FMH ISFM, 2002b). Both forms characterize the successful completion of a shorter training section than a specialist training and are not a specialist title ( $\ddot{A} A O$, 2015; SIWF FMH ISFM, 2000; SIWF FMH ISFM, 2002b). In Germany, these terms are still used as colloquial language, although these names no longer exist officially with the amendment of the German training regulations.

\section{Conclusion}

Compared to other countries at European and international level, the specialist's training in internal medicine can be considered very similar between the three countries. The main differences are the access requirements, the linkage of the qualification to the independent exercise of the medical profession to the specialist title and the performance catalogues, which are similar in the requirements with a predefined number of performances to be executed in Germany and Austria, but differ from the Swiss approach of competence levels. This also facilitates the recognition of the training periods and the specialist's title, which is the reason for the high mobility of young physicians between Germany, Austria and Switzerland during or after the continuing education as a specialist in internal medicine. This may be a possibility for compensating the emigrationrelated supply bottlenecks via immigration from the other countries. However, further studies are needed for the empirical proof of these relationships.

\section{Acknowledgements}

This publication contains results from the thesis of Johanna Braun "Vergleich der Weiterbildung zum Facharzt der Inneren Medizin zwischen den Ländern Deutschland, Österreich und Schweiz mit Ausblick auf die Europäische Union” submitted at the Medical Faculty of the Ludwig-Maximilians University of Munich.

\section{References}

ÄAO (2015). Verordnung der Bundesministerin für Gesundheit über die Ausbildung zur Ärztin für Allgemeinmedizin/zum Arzt für Allgemeinmedizin und zur Fachärztin/zum Facharzt (Ärztinnen-/Ärzte-Ausbildungsordnung 2015-ÄAO 2015). http://www.aerztekammer.at/arzte-ausbildungsordnung

Adler, G., \& Knesebeck, J. H. (2011). Ärztemangel und Ärztebedarf in Deutschland? Fragen an die Versorgungsforschung. Bundesgesundheitsbl, 54, 228-237. https://doi.org/10.1007/s00103-010-1208-7

ÄrzteG (1998). Bundesgesetz über die Ausübung des ärztlichen Berufes und die Standesvertretung der Ärzte (ÄrzteG 1998).

https://www.ris.bka.gv.at/GeltendeFassung.wxe?Abfrage=Bundesnormen\&Gesetzesnu $\underline{\text { mmer }=10011138}$

BAG (Federal Department of Health) (2016a). Medizinalberufestatistik 2015. Bern: Bundesamt für Gesundheit.

BÄK (German Medical Association) (2003). (Muster-) Weiterbildungsordnung 2003 in der Fassung vom 23.10.2015. 
http://www.bundesaerztekammer.de/aerzte/aus-weiter-fortbildung/weiterbildung/must er-weiterbildungsordnung/

BÄK (German Medical Association) (2003b). (Muster-) Richtlinie über den Inhalt der Weiterbildung (MWBO 2003) in der Fassung vom 18.02.2011.

http://www.bundesaerztekammer.de/fileadmin/user_upload/downloads/RiliMWBO20 110218.pdf

BÄK (German Medical Association) (2011a). Ärztestatistik 2010.

http://www.bundesaerztekammer.de/ueber-uns/aerztestatistik/aerztestatistik-der-vorja $\underline{\text { hre/aerztestatistik-2010/ }}$

BÄK (German Medical Association) (2011b). (Muster) Berufsordnung für die in Deutschland tätigen Ärztinnen und Ärzte in der Fassung der Beschlüsse des 114. Deutschen Arrtetages in Kiel.

http://www.bundesaerztekammer.de/fileadmin/user_upload/downloads/MBO_08_201 12.pdf

BÄK (German Medical Association) (2012). Ärztestatistik 2011.

http://www.bundesaerztekammer.de/ueber-uns/aerztestatistik/aerztestatistik-der-vorja hre/aerztestatistik-2011/

BÄK (German Medical Association) (2013a). Ärztestatistik 2012.

http://www.bundesaerztekammer.de/ueber-uns/aerztestatistik/aerztestatistik-der-vorja hre/aerztestatistik-2012/

BÄK (German Medical Association) (2013b). (Muster-) Fortbildungsordnung in der Fassung vom 29.05.2013. Berlin: Bundesärztekammer.

http://www.bundesaerztekammer.de/fileadmin/user_upload/downloads/_Muster-_Fort bildungsordnung_29052013.pdf

BÄK (German Medical Association) (2014a). Ärztestatistik 2013.

http://www.bundesaerztekammer.de/ueber-uns/aerztestatistik/aerztestatistik-der-vorja hre/aerztestatistik-2013/

BÄK (German Medical Association) (2014b). Satzung der Bundesärztekammer, Arbeitsgemeinschaft der Deutschen Ärztekammern (in der vom 117. Deutschen Ärztetag 2014 beschlossenen Fassung). Berlin: Bundesärztekammer.

BÄK (German Medical Association) (2015). Ärztestatistik 2014.

http://www.bundesaerztekammer.de/ueber-uns/aerztestatistik/aerztestatistik-2014/

BÄK (German Medical Association) (2016a). Ärztestatistik 2015.

http://www.bundesaerztekammer.de/ueber-uns/aerztestatistik/aerztestatistik-2015/

BÄK (German Medical Association) (2016b). Die Bundesärztekammer.

http://www.bundesaerztekammer.de/ueber-uns

BÄO (Federal Medical Code) (1961). Bundesärzteordnung in der Fassung der Bekanntmachung vom 16. April 1987 (BGBI. I S. 1218), die durch Artikel 5 des Gesetzes vom 23. Dezember 2016 (BGBl. I S. 3191) geändert worden ist.

http://www.gesetze-im-internet.de/b_o/BJNR018570961.html

BFS (Federal Department of Statistics) (2015). Bestand und Dichte der Ärzte, Zahnärzte und Apotheken nach Kanton. Stand: 17.08.2015. Neuchâtel: Bundesamt für Statistik.

Bundesrat (Swiss Federal Council) (2011). Bericht des Bundesrates. Strategie gegen Ärztemangel und zur Förderung der Hausarztmedizin. Bern: Bundesrat.

EUR-Lex (2005). Directive 2005/36/EC of the European Parliament and of the Council of 7 September 2005 on the Recognition of Professional Qualifications. http://eur-lex.europa.eu/LexUriServ/LexUriServ.do?uri=CONSLEG:2005L0036:200812 11:DE:PDF 
Fisch, S. (2008). Medizinstudium-Ius Practicandi-Was nun? Facharztausbildung in Österreich. Wien: Springer.

FMH (Swiss Medical Association) (1998). Statuten FMH in der Fassung vom 24. Bern: FMH.

FMH (Swiss Medical Association) (2016a). Porträt-Die FMH Stellt Sich vor. http://www.fmh.ch/ueber_fmh/portraet.html

Freizügigkeitsabkommen (Agreement on the Free Movement of Persons) (1999). $A b$ kommen Zwischen der Schweizerischen Eidgenossenschaft Einerseits und der Europäischen Gemeinschaft und Ihren Mitgliedstaaten Andererseits über die Freizügigkeit.

https://www.admin.ch/opc/de/classified-compilation/19994648/201506080000/0.142.11 2.681.pdf

Hammer, T. (2015). Eine Chance Auch für Deutsche Ärzte.

HKaG (Bavarian Healing Professions Chamber Act) (2002). Gesetz über die Berufsausübung, die Berufsvertretungen und die Berufsgerichtsbarkeit der Ärzte, Zahnärzte, Tierärzte, Apotheker sowie der Psychologischen Psychotherapeuten und der Kinderund Jugendlichenpsychotherapeuten (Heilberufe-Kammergesetz-HKaG). http://www.gesetze-bayern.de/Content/Document/BayHKaG/t

Hostettler, S., \& Kraft, E. (2016). FMH-Ärztestatistik 2015. Schweizerische Ärztezeitung, 97, 448-453.

Jaccard Ruedin, H., \& Widmer, M. (2010). Ausländisches Gesundheitspersonal in der Schweiz (Obsan Bericht 39). Neuchâtel: Schweizerisches Gesundheitsobservatorium.

Kopetsch, T. (2010). Dem deutschen Gesundheitswesen gehen die Ärzte aus! Berlin: BÄK und Kassenärztliche Bundesvereinigung.

Kraft, E., \& Hersperger, M. (2011). Auch dank Frauen und Ausländern ist die Ärztliche Versorgung in der Schweiz Garantiert. Schweizerische Ärztezeitung, 92, 49.

MedBG (Federal Law on Medical Professions) (2006). Bundesgesetz über die Universitären Medizinalberufe SR 811.11 vom 23. Juni 2006.

https://www.admin.ch/opc/de/classified-compilation/20040265/index.html

ÖÄK (Austrian Medical Association) (2006). Verordnung der Österreichischen Ärztekammer über eine Richtlinie für die Laufende Fachliche Fortbildung von Ärzten (Diplom-Fortbildungs-Programm der Österreichischen Ärztekammer; DFP-Richtlinie) Beschlossen Gemäß S 118 Abs 2 Z 17 iVm S 122 Z 6 Ärztegesetz 1998 von der Vollversammlung der Österreichischen Ärztekammer am 16 Dezember 2006. Wien: Österreichische Ärztekammer.

ÖÄK (Austrian Medical Association) (2010). Verordnung über Ärztliche FortbildungKonsolidierte Fassung ab 1. September 2013. Wien: Österreichische Ärztekammer.

ÖÄK (Austrian Medical Association) (2015a). Verordnung der Österreichischen Ärztekammer über Kenntnisse, Erfahrungen und Fertigkeiten in der Ausbildung zur Ärztin für Allgemeinmedizin/zum Arzt für Allgemeinmedizin und zur Fachärztin/zum Facharzt, sowie über die Ausgestaltung und Form der Rasterzeugnisse, Prüfungszertifikate und Ausbildungsbücher (KEF und RZ-V 2015). Wien: Österreichische Ärztekammer.

ÖÄK (Austrian Medical Association) (2015b). Ärzteausbildung 2015. Sonderausgabe der Österreichischen Ärztezeitung. Wien: Österreichische Ärztekammer.

ÖÄK (Austrian Medical Association) (2015c). Ausbildungsinhalte zum Sonderfach Innere Medizin. Wien: Österreichische Ärztekammer.

ÖÄK (Austrian Medical Association) (2016a). Mission Statement. 
http://www.aerztekammer.at/organisation

Orchard, T. J., Nathan, D. M., Zinman, B., Clearly, P., Brillon, D., Backlund, J. C., \& Lachin, J. M. (2015). Association between 7 Years of Intensive Treatment of Type 1 Diabetes and Long-Term Mortality. JAMA, 313, 45-53.

https://doi.org/10.1001/jama.2014.16107

Scharer, S., \& Freitag, A. (2015). Physicians' Exodus: Why Medical Graduates Leave Austria or Do Not Work in Clinical Practice. Wien Klein Wochenschr, 127, 323-329. https://doi.org/10.1007/s00508-015-0786-7

Schmidt, S. (2014). Entwicklung der Ärztlichen Versorgung in Bayern unter Berücksichtigung des Steigenden Anteils an Ausländischen Ärztinnen und Ärzten mit Darstellung der Aktuellen Personalsituation Anhand einer Befragung Bayerischer Krankenhäuser. München: Ludwig-Maximilians-Universität in Munich.

Schmidt, S., \& Gresser, U. (2014). Entwicklung und Konsequenzen des Ärztemangels in Bayern. Versicherungsmedizin, 66, 25-29.

Sieber, C. C. (2007). Der ältere Patient-Wer ist das? Der Internist, 48, 1190-1194. https://doi.org/10.1007/s00108-007-1945-3

SIWF FMH ISFM (Swiss Institute for Postgraduate and Further Education in Medicine, Swiss Medical Association) (2000). Weiterbildungsordnung (WBO). 21. Juni 2000. Revision vom 10. September 2015. Bern: Schweizerisches Institut für Ärztliche WeiterUnd Fortbildung.

SIWF FMH ISFM (Swiss Institute for Postgraduate and Further Education in Medicine, Swiss Medical Association) (2002a). Fortbildungsordnung (FBO) 25. April 2002 (letzte Revision: 6. November 2014). Bern: Schweizerisches Institut für Ärztliche Weiter-Und Fortbildung.

SIWF FMH ISFM (Swiss Institute for Postgraduate and Further Education in Medicine, Swiss Medical Association) (2002b). Praktischer Arzt/Praktische Ärztin-Weiterbildungsprogramm vom 1. Juni 2002 (letzte Revision: 5. Dezember 2013). Bern: Schweizerisches Institut für Ärztliche Weiter-Und Fortbildung.

SIWF FMH ISFM (Swiss Institute for Postgraduate and Further Education in Medicine, Swiss Medical Association) (2011). Facharzt für Allgemeine Innere Medizin-Weiterbildungsprogramm vom 1. Januar 2011 (letzte Revision: 3. November 2016). Bern: Schweizerisches Institut für Ärztliche Weiter-Und Fortbildung.

SIWF FMH ISFM (Swiss Institute for Postgraduate and Further Education in Medicine, Swiss Medical Association) (2016a). Lernzielkatalog. Allgemeine Lernziele für die Weiterbildungsprogramme (gemäss Art. 3 Abs. 2 WBO). Bern: Schweizerisches Institut für Ärztliche Weiter-Und Fortbildung.

SIWF FMH ISFM (Swiss Institute for Postgraduate and Further Education in Medicine, Swiss Medical Association) (2016b). Anhang 1. Lernziele Basisweiterbildung. Bern: Schweizerisches Institut für Ärztliche Weiter-Und Fortbildung.

SIWF FMH ISFM (Swiss Institute for Postgraduate and Further Education in Medicine, Swiss Medical Association) (2016c). Anhang 3. Lernziele Spitalinternist. Bern: Schweizerisches Institut für Ärztliche Weiter-Und Fortbildung.

SIWF FMH ISFM (Swiss Institute for Postgraduate and Further Education in Medicine, Swiss Medical Association) (2016d). Anhang 2. Lernziele Hausarzt. Bern: Schweizerisches Institut für Ärztliche Weiter-Und Fortbildung.

Stackelberg, J. M. (2010). Pro \& Contra: Ärztemangel in Deutschland?-Die Sicht des GKV-Spitzenverbandes. Die Krankenversicherung, 4, 113.

Statista (2016a). Anzahl Ambulanter und Stationärer Ärzte in Deutschland nach Fachge- 
biet im Jahr 2013-2015.

http://de.statista.com/statistik/daten/studie/190312/umfrage/anzahl-ambulanter-und-st ationaerer-aerzte-nach-fachgebiet/

Statista (2016b). Anteil Ausländischer Arztdiplome in der Schweiz im Jahr 2014. https://de.statista.com/statistik/daten/studie/296877/umfrage/anteil-auslaendischer-arz tdiplome-in-der-schweiz/

Statistik Austria (Statistics Austria) (2016a). Personal im Gesundheitswesen. http://www.statistik.at/web_de/statistiken/menschen_und_gesellschaft/gesundheit/ges undheitsversorgung/personal_im_gesundheitswesen/index.html

Statistisches Bundesamt (German Federal Statistical Office) (2011). Ab in die Schweiz? Ärzte im Wanderfieber. Wiesbaden: Statistisches Bundesamt 2011.

Statistisches Bundesamt (German Federal Statistical Office) (2015): Bevölkerung Deutschlands bis 2060. Wiesbaden: Statistisches Bundesamt.

Van den Bussche, H., Kromark, K., Köhl-Hackert, N., Robra, B., Rothe, K., Schmidt, A., Stosch, C., Wagner, R., Wonnenberger, C., Scherer, M., Alfermann, D., \& Gedrose, B. (2012). Hausarzt oder Spezialist im In-Oder Ausland? Gesundheitswesen, 74, 786-792. https://doi.org/10.1055/s-0032-1311619

Wismar, M., Maier, C. B., Glinos, I. A., Dussault, G., \& Figueras, J. (2011). Health Professional Mobility and Health Systems. Brussels: European Observatory on Health Systems and Policies.

Zimmermann, M., \& Purger, A. (2015). Warum Österreichs Ärzte Abwandern.

Submit or recommend next manuscript to SCIRP and we will provide best service for you:

Accepting pre-submission inquiries through Email, Facebook, LinkedIn, Twitter, etc. A wide selection of journals (inclusive of 9 subjects, more than 200 journals)

Providing 24-hour high-quality service

User-friendly online submission system

Fair and swift peer-review system

Efficient typesetting and proofreading procedure

Display of the result of downloads and visits, as well as the number of cited articles

Maximum dissemination of your research work

Submit your manuscript at: http://papersubmission.scirp.org/

Or contact ce@scirp.org 